Prosiding Seminar Nasional Teknologi Informasi dan Kedirgantaraan : Transformasi Teknologi untuk Mendukung Ketahanan Nasional, Yogyakarta, 13 Desember 2018

SENATIK 2018, Vol. IV, ISBN 978-602-52742-0-6

DOI: http://dx.doi.org/10.28989/senatik.v4i0.222

\title{
DESIGN OF EXPERT SYSTEM DIARRHEA FOR TODDLER USING K- NEAREST NEIGHBOR ALGORITHM (K-NN)
}

\section{Esi Putri Silmina, Tikaridha Hardiani}

Program Studi Teknologi Informasi Fakultas Sains dan Teknologi

Universitas 'Aisyiyah Yogyakarta

Jl. Ringroad Barat No.63, Mlangi, Nogotirto, Gamping, Sleman, Yogyakarta

Email : esiputrisilmina@unisayogya.ac.id

\begin{abstract}
Diarrhea is one of the main causes of death in children under the age of 5 years. Based on reports from the World Health Organization (WHO), 1 in 10 children died of diarrhea with 800,000 deaths per child. When toddlers suffer from diarrhea there are obstacles faced by parents when having to consult a pediatrician, for that we need a system that can store the expertise of an expert in this case a pediatrician in dealing with diarrheal diseases that occur in infants. The K-NN (K-Nearest Neighbor) algorithm was developed in this research expert system. The variables used were 14 symptoms where diarrheal diseases were classified into 6 types. The results of distance calculation show testing data (new cases) No RM 4247 approaching 3 training data (old cases) with a distance value of 2.24. The addition of the calculation of similarity in the calculation strengthens the results of the diagnosis, with the largest similarity value of 79\% at No RM 1090, then the testing data (new cases) didignosis mild acute dehydration diarrhea.
\end{abstract}

Keyword: expert system, diarrhea, toddler, K-Nearest Neighbor Algorithm

\section{Pendahuluan}

Diare adalah buang air besar (defekasi) dengan tinja berbentuk cair atau setengah cair (setengah padat), kandungan air tinja lebih banyak dari biasanya lebih dari $200 \mathrm{~g}$ atau 200 $\mathrm{ml} / 24$ jam. Definisi lain memakai kriteria frekuensi, yaitu buang air besar encer lebih dari 3 kali per hari. Buang air besar encer tersebut dapat/tanpa disertai lendir dan darah [2, 12]. Diare akut sampai saat ini masih merupakan masalah kesehatan, tidak saja di negara berkembang tetapi juga di negara maju. Penyakit diare masih sering menimbulkan KLB (Kejadian Luar Biasa) dengan penderita yang banyak dalam waktu yang singkat, dengan CRF yang sangat tinggi $[5,6]$.

Penyakit diare merupakan salah 1 penyebab utama kematian pada anak di bawah usia 5 tahun. Berdasarkan laporan dari World Health Organization (WHO), 1 dari 10 anak meninggal akibat diare dengan jumlah kematian 800.000 anak setiap tahun [11]. Penyebab kematian untuk semua umur telah terjadi pergeseran, dari penyakit menular ke penyakit tidak menular. Penyebab kematian bayi yang terbanyak adalah diare $(31,4 \%)$ dan pnemonia $(23,8 \%)$. Sedangkan untuk penyebab kematian anak balita sama dengan bayi, yaitu terbanyak adalah diare $(25,2 \%)$ dan pnemonia $(15,5 \%)$ [7]. Insiden dan period prevalence diare untuk seluruh kelompok umur di Indonesia adalah 3,5 persen dan 7,0 persen. Lima provinsi dengan insiden maupun period prevalen diare tertinggi adalah Papua, Sulawesi Selatan, Aceh, Sulawesi Barat, dan Sulawesi Tengah. Insiden diare pada kelompok usia balita di Indonesia adalah 10,2 persen. Lima provinsi dengan insiden diare tertinggi adalah Aceh, Papua, DKI Jakarta, Sulawesi Selatan, dan Banten [8].

Berdasarkan data tersebut maka penyakit diare merupakan penyakit serius untuk ditangani. Kekhawatiran orang tua ketika mengadapi buah hatinya mengidap penyakit diare terutama pada usia balita membuat kepanikan tersendiri, orang tua lebih mempercayakan 
dokter spesialis anak dalam penanganan suatu kasus penyakit diare. Akan tetapi terdapat kendala yang dihadapi orang tua ketika harus berkonsultasi dengan dokter spesialia anak, diantaranya keterbatasan waktu jam praktek dokter anak, yang tidak bisa ditemui kapan saja dan antrian panjang ketika akan berkonsultasi. Berdasarkan pada keadaan tersebut diperlukan suatu sistem yang bisa menyimpan keahlian seorang pakar dalam hal ini dokter spesialis anak dalam menangani penyakit diare yang terjadi pada balita.

Sistem pakar (Expert System) merupakan suatu sistem terkomputerisasi yang menggunakan pengetahuan bidang tertentu untuk mencapai solusi suatu masalah dari bidang tersebut. Solusi yang diberikan pada dasarnya sema seperti yang disimpulkan oleh pakar ayng banyak mengetahui masalah tersebut. Sistem pakar (Expert System) sebagai bidang studi dalam ilmu Artificial Intellegent (AI) kini telah berkembang selama beberapa dekade. Sejak didirikan pada tahun 1970-an, sistem pakar telah mengalami perkembangan dengan banyaknya studi kasus di tahun 1980-an dan 1990-an [10].

Gejala-gejala penyakit diare yang terjadi pada balita dapat dikenali pada setiap kasusnya. Gejala-gejala tersebut harus diklasifikasikan agar diperoleh kecocokan terhadap rule (aturan diagnosis) penyakit diare, sehingga diagnosis penyakit diare dapat diketahui. Salah satu algoritma untuk mengklasifikasikan data adalah K-Nearest Neighbor $(K-N N)$. Algoritma K-Nearest Neighbor $(K-N N)$ berfungsi mengklasifikasikan sekumpulan data berdasarkan kedekatan terhadap sekumpulan data yang telah terklasifikasikan sebelumya [14]. Algoritma K-NN dapat digunakan pada sistem pakar yang dirancang untuk mengklasifikasikan kumpulan gejala yang dimasukkan pengguna (user) kemudian mencocokkan kedalam rule penyakit diare. Dengan demikian sistem pakar ini dapat dibuat untuk mendiagnosis penyakit diare pada balita.

Penelitian dalam bidang sistem pakar yang pernah dilakukan sebelumnya, diantaranya sistem pakar berjudul Aplikasi Sistem Pakar untuk Mendiagnosa Penyakit Bayi dan Balita Berbasis Android dengan Menggunakan Algoritma Depth First Serch [9]. Penelitian dengan judul Sistem Pakar Untuk Mendiagnosa Penyakit Dan Hama Pada Tanaman Salak Di Turi Sleman [3]. Sedangkan penelitian ini akan merancang suatu sistem pakar yang dapat mengdiagnosis penyakit diare pada balita dengan menggunakan Algorima K-Nearest Neighbor (K-NN), sehingga orang tua dapat menangani sejak dini penyakit diare pada balita dan menurunkan angka kematian balita yang disebabkan oleh penyakit diare.

\section{Metodologi Penelitian}

Metode penelitian dalam penelitian ini yaitu:

a. Analisis Sistem

Tahap analisis dilakukan secara keseluruhan baik fungsional maupun non fungsional sistem. Menentukan gejala apa saja yang terjadi pada penyakit diare dilakukan pada tahap analisis sistem.

b. Observasi

Tahap observasi meliputi wawancara dan analisis data. Wawancara dilakukan untuk mengetahui gejala-gejala yang terjadi pada penyakit diare beserta jenis diare yang terjadi pada balita. Pakar yang diwawancara pada penelitian ini yaitu dokter spesialis anak.

c. Perancangan Sistem

Tahap perancangan sistem dilakukan untuk membuat usecase, merancang database, dan merancang antarmuka sistem pakar untuk diagnosis penyakit diare pada balita.

d. Pengujian 
Tahap pengujian akan mengitung data kasus diare sebelum dimasukan ke dalam listing program. Perhitungan dilakukan berapa kali agar didapatkan hasil yang maksimal.

\section{Hasil dan Pembahasan}

Algoritma K-Nearest Neighbor dikenal dengan 2 jenis data yaitu data training dan data testing. Data training (kasus lama) diambil dari data pasien yang ada pada rekam medis rumah sakit swasta di Yogyakarta. Sedangkan data testing (kasus baru) adalah data kasus baru yang akan diinputkan pada sistem dan akan didiagnosis, untuk memutuskan pasien tersebut terkena penyakit diare atau tidak. Data training dan data testing dicari kedekatannya, data pasien (data training) yang paling dekat dengan data testing akan menghasilkan diagnosis yang sama, sehingga pasien tersebut dapat diberikan saran untuk ke rumah sakit terdekat.

\subsection{Analisis}

Tahapan analisis akan dilakukan untuk menentukan gejala penyakit diare yang terjadi pada balita. Gejala dari penyakit diare akan diberikan bobot berdasarkan rule yang sudah dibuat oleh pakar yaitu dokter spesialis anak. Skor bobot (w) ini ditentukan berdasarkan kepentingan setiap gejala. Jika gejala tersebut adalah gejala yang penting terhadap penyakit diare maka di beri bobot 5, jika gejala tersebut kepentingannya sedang terhadap penyakit diare maka diberi bobot 3, dan kepentingan gejala tersebut biasa diberi bobot 1 .

\subsection{Variabel}

Penyakit diare dapat dibedakan menjadi 2 jeni yaitu diare akut dan diare persisten. Diare akut adalah buang air besar lebih dari 3 kali dalam 24 jam dengan konsistensi cair dan berlangsung kurang dari 1 minggu [4]. Diare persisten adalah diare akut dengan atau tanpa disertai darah dan berlanjut sampai 14 hari atau lebih. Jika terdapat dehidrasi sedang atau berat, diare persisten diklasifikasikan sebagai berat. Jadi diare persisten adalah bagian dari diare kronik yang disebabkan oleh berbagai penyebab [13]. Semua anak dengan diare, harus diperiksa apakah menderita dehidrasi dan klasifikasikan status dehidrasi sebagai dehidrasi berat, dehidrasi ringan/ sedang atau tanpa dehidrasi dan beri pengobatan yang sesuai [4] . Gejala dan bobot penyakit serta klasifikasi dehidrasi penyakit diare dapat dilihat pada Tabel 1.

Tabel 1 Gejala dan Bobot Penyakit Diare Beserta Klasifikasi Dehidrasi

\begin{tabular}{|c|l|c|}
\hline $\begin{array}{c}\text { Kode } \\
\text { Gejala }\end{array}$ & \multicolumn{1}{|c|}{ Gejala } & Bobot \\
\hline G1 & Frekuensi buang air besar (BAB) anak > 3 kali dalam 24 jam & 1 \\
\hline G2 & Lamanya diare terjadi (berapa hari) < 7 hari & 3 \\
\hline G3 & Lamanya diare terjadi (berapa hari) > 14 hari & 5 \\
\hline G4 & Tidak ada darah dalam tinja & 1 \\
\hline G5 & ada darah dalam tinja & 3 \\
\hline G6 & Ada muntah & 1 \\
\hline G7 & Tidak Ada muntah & 3 \\
\hline G8 & Rewel, gelisah & 5 \\
\hline G9 & Letargis/tidak sadar \\
\hline
\end{tabular}




\begin{tabular}{|c|l|c|}
\hline G10 & Mata cekung & 3 \\
\hline G11 & Minum dengan lahap, haus & 3 \\
\hline G12 & $\begin{array}{l}\text { Tidak bisa minum atau malas } \\
\text { minum }\end{array}$ & 5 \\
\hline G13 & Cubitan kulit kembali lambat & 3 \\
\hline G14 & $\begin{array}{l}\text { Cubitan kulit perut kembali } \\
\text { sangat lambat ( } \geq 2 \text { detik) }\end{array}$ & 5 \\
\hline
\end{tabular}

Berdasarkan dari semua gejala yang ada akan ditentukan jenis diare dan juga klasifikasi dehidrasi yang terjadi pada pasien termasuk pada klasifikasi tanpa dehidrasi, dehidrasi ringan/sedang atau dehidrasi berat seperti yang terlihat pada Tabel 2.

Tabel 2 Jenis Diare dan Klasifikasi Dehidrasi

\begin{tabular}{|c|c|c|c|c|c|c|}
\hline $\begin{array}{l}\text { Kode } \\
\text { Gejala }\end{array}$ & $\begin{array}{c}\text { Diare Akut } \\
\text { Tanpa } \\
\text { Dehidrasi }\end{array}$ & $\begin{array}{c}\text { Diare } \\
\text { Akut } \\
\text { Dehidrasi } \\
\text { Ringan } \\
\end{array}$ & $\begin{array}{c}\text { Diare } \\
\text { Akut } \\
\text { Dehidrasi } \\
\text { Berat } \\
\end{array}$ & $\begin{array}{c}\text { Diare } \\
\text { Persisten } \\
\text { Tanpa } \\
\text { Dehidrasi }\end{array}$ & $\begin{array}{c}\text { Diare } \\
\text { Persisten } \\
\text { Dehidrasi } \\
\text { Ringan } \\
\end{array}$ & $\begin{array}{c}\text { Diare } \\
\text { Persisten } \\
\text { Dehidrasi } \\
\text { Berat }\end{array}$ \\
\hline G1 & $\mathrm{Ya}$ & Ya & Ya & $\mathrm{Ya}$ & Ya & $\mathrm{Ya}$ \\
\hline $\mathrm{G} 2$ & $\mathrm{Ya}$ & $\mathrm{Ya}$ & $\mathrm{Ya}$ & & & \\
\hline G3 & & & & $\mathrm{Ya}$ & $\mathrm{Ya}$ & $\mathrm{Ya}$ \\
\hline G4 & $\mathrm{Ya}$ & $\mathrm{Ya}$ & $\mathrm{Ya}$ & $\mathrm{Ya}$ & $\mathrm{Ya}$ & $\mathrm{Ya}$ \\
\hline G5 & & & & $\mathrm{Ya}$ & $\mathrm{Ya}$ & $\mathrm{Ya}$ \\
\hline G6 & $\mathrm{Ya}$ & $\mathrm{Ya}$ & $\mathrm{Ya}$ & $\mathrm{Ya}$ & $\mathrm{Ya}$ & $\mathrm{Ya}$ \\
\hline G7 & $\mathrm{Ya}$ & $\mathrm{Ya}$ & $\mathrm{Ya}$ & $\mathrm{Ya}$ & $\mathrm{Ya}$ & $\mathrm{Ya}$ \\
\hline G8 & & $\mathrm{Ya}$ & & & $\mathrm{Ya}$ & \\
\hline G9 & & & $\mathrm{Ya}$ & & & $\mathrm{Ya}$ \\
\hline G10 & & $\mathrm{Ya}$ & $\mathrm{Ya}$ & & $\mathrm{Ya}$ & $\mathrm{Ya}$ \\
\hline G11 & & $\mathrm{Ya}$ & & & $\mathrm{Ya}$ & \\
\hline G12 & & & $\mathrm{Ya}$ & & & $\mathrm{Ya}$ \\
\hline G13 & & $\mathrm{Ya}$ & & & $\mathrm{Ya}$ & \\
\hline G14 & & & $\mathrm{Ya}$ & & & $\mathrm{Ya}$ \\
\hline
\end{tabular}

\subsection{Prinsip Kerja K-Nearest Neighbour (K-NN)}

Prinsip kerja K-Nearest Neighbour (K-NN) adalah mencari jarak terdekat antara data yang akan dievaluasi dengan $k$ tetangga (Neighbour) terdekatnya dalam data pertestingan. Berikut urutan proses kerja K-NN [1]:

1. Menentukan parameter $k$ (jumlah tetangga paling dekat).

2. Menghitung kuadrat jarak Euclidean Distance masing-masing objek (data training) terhadap data sampel yang diberikan pada persamaan (1):

$$
d_{i}=\sqrt{\sum_{i=1}^{p}\left(x_{2 i}-x_{1 i}\right)^{2}}
$$

Keterangan:

$\mathrm{x}_{1}$ : Sampel data/data training

$\mathrm{x}_{2}$ : Data uji/testing

i : Variabel data

d : Jarak

$\mathrm{p}$ : Dimensi data 
3. Mengurutkan objek-objek tersebut dalam kelompok yang mempunyai jarak Euclidean terkecil

4. Mengumpulkan kategori y (kelas dari objek terdekat) sebanyak k

Algoritma K-Nearest Neighbor (K-NN) juga dilakukan untuk K-Nearest Neighbor (K-NN) improved dengan menggunakan jarak similaritas. Cara perhitungan similaritas digunakan persamaan (2):

Similarity $($ Problem, case $)=\frac{s 1 * w 1+s 2 * w 2+\cdots+s n * w n}{w 1+s w 2+\cdots+w n}$

Keterangan:

S : Similarity (kemiripan)

W : Bobot yang diberikan

\section{a. Data Training}

Tabel 3 data training (kasus lama) untuk gejala penyakit diare jumlahnya 15 data training, tapi yang ditampilkan untuk data training ada 5 data. Tabel 3 menunjukan gejala yang dialami pasien, jika pasien mengalamai gejala Frekuensi buang air besar (BAB) anak > 3 kali dalam 24 jam, maka sistem akan mengenali dengan "Ya", sedangkan jika gejala tidak dialami pada pasien maka sistem mengenali dengan "Tidak". Keterangan pada Tabel 3 menjelaskan jenis diare beserta klasifikasi dehidrasinya.

Tabel 3 Pasien dan Gejala Penyakit Diare

\begin{tabular}{|c|c|c|c|c|c|}
\hline No RM & 2347 & 7689 & 1090 & 3452 & 2789 \\
\hline G1 & $\mathrm{Ya}$ & $\mathrm{Ya}$ & $\mathrm{Ya}$ & $\mathrm{Ya}$ & $\mathrm{Ya}$ \\
\hline $\mathrm{G} 2$ & $\mathrm{Ya}$ & $\mathrm{Ya}$ & $\mathrm{Ya}$ & & $\mathrm{Ya}$ \\
\hline G3 & & & & Ya & \\
\hline G4 & $\mathrm{Ya}$ & $\mathrm{Ya}$ & $\mathrm{Ya}$ & & $\mathrm{Ya}$ \\
\hline G5 & & & & Ya & \\
\hline G6 & & $\mathrm{Ya}$ & & $\mathrm{Ya}$ & \\
\hline G7 & $\mathrm{Ya}$ & & $\mathrm{Ya}$ & & $\mathrm{Ya}$ \\
\hline G8 & & Ya & $\mathrm{Ya}$ & & $\mathrm{Ya}$ \\
\hline \multicolumn{6}{|l|}{ G9 } \\
\hline G10 & & $\mathrm{Ya}$ & $\mathrm{Ya}$ & $\mathrm{Ya}$ & \\
\hline G11 & & $\mathrm{Ya}$ & $\mathrm{Ya}$ & & $\mathrm{Ya}$ \\
\hline G12 & & & & $\mathrm{Ya}$ & \\
\hline G13 & & & & & Ya \\
\hline G14 & & & & $\mathrm{Ya}$ & \\
\hline Keterangan & $\begin{array}{c}\text { Diare Akut } \\
\text { Tanpa } \\
\text { Dehidrasi }\end{array}$ & $\begin{array}{c}\text { Diare Akut } \\
\text { Dehidrasi } \\
\text { Ringan }\end{array}$ & $\begin{array}{c}\text { Diare Akut } \\
\text { Dehidrasi } \\
\text { Ringan }\end{array}$ & $\begin{array}{c}\text { Diare } \\
\text { Persisten } \\
\text { Berat }\end{array}$ & $\begin{array}{c}\text { Diare Akut } \\
\text { Dehidrasi } \\
\text { Ringan }\end{array}$ \\
\hline
\end{tabular}

\section{b. Data Testing}

Data Testing adalah data dari pasien (kasus baru) yang akan ditentukan diagnosisnya dari gejala-gejala yang ada, data testing (kasus baru) akan dicocokan dengan data training (kasus lama) untuk mencari data terdekatnya, Tabel 4 adalah contoh data testing (kasus baru). 
Tabel 4 Pasien dan Gejala Penyakit Diare

\begin{tabular}{|c|c|}
\hline NO RM & $\mathbf{4 2 4 7}$ \\
\hline G1 & Ya \\
\hline G2 & Ya \\
\hline G3 & \\
\hline G4 & \\
\hline G5 & Ya \\
\hline G6 & Ya \\
\hline G7 & \\
\hline G8 & Ya \\
\hline G9 & \\
\hline G10 & Ya \\
\hline G11 & Ya \\
\hline G12 & \\
\hline G13 & Ya \\
\hline G14 & \\
\hline Keterangan & $?$ \\
\hline
\end{tabular}

Perhitungan jarak dan similarity antara kasus data training (kasus lama) dengan data testing (kasus baru) menggunakan persamaan (1) dan persamaan (2). Hasil perhitungan jarak dan similarity dapat dilihat pada Tabel 5.

Tabel 5 Hasil Perhitungan Jarak dan Similarity

\begin{tabular}{|c|c|c|l|}
\hline No RM & Jarak & Similarity & \multicolumn{1}{|c|}{ Keterangan } \\
\hline 2347 & 2,45 & $60 \%$ & $\begin{array}{l}\text { Diare Akut Tanpa } \\
\text { Dehidrasi }\end{array}$ \\
\hline 7689 & 2,24 & $76 \%$ & $\begin{array}{l}\text { Diare Akut Dehidrasi } \\
\text { Ringan }\end{array}$ \\
\hline 1090 & 2,24 & $79 \%$ & $\begin{array}{l}\text { Diare Akut Dehidrasi } \\
\text { Ringan }\end{array}$ \\
\hline 3452 & 2,64 & $36 \%$ & $\begin{array}{l}\text { Diare Persisten } \\
\text { Ringan }\end{array}$ \\
\hline 2789 & 2,24 & $76 \%$ & $\begin{array}{l}\text { Diare Akut Dehidrasi } \\
\text { Ringan }\end{array}$ \\
\hline
\end{tabular}

Hasil perhitungan pada Tabel 5 menunjukkan bahwa kasus diare dengan No RM 4247 memiliki jarak terdekat dengan 3 kasus diare dengan No RM 7689, No RM 1090 dan No RM 2789 yaitu 2,24. Penambahan perhitungan nilai similarity memperkuat diagnosis kasus diare No RM 4247 dengan hasil similarity tertinggi pada kasus No RM 1090 yaitu 79\%, sehingga data testing (kasus baru) dengan No Rm 4247 didiagnosisi Diare Persisten Ringan.

Perhitungan data training (kasus lama) dengan No RM 1090 dengan data testing (kasus baru) dengan No RM 4247:

Similarity $(4247,1090)$

$$
\begin{aligned}
& =(1 * 1+1 * 3+1 * 5+0 * 1+0 * 3+0 * 3+0 * 1+1 * 3+1 * 5+1 \\
& * 3+1 * 3+1 * 5+0 * 3+1 * 5 /(1+3+5+1+3+1+1+3+5+3 \\
& +3+5+3+5)=\frac{33}{42}=79 \%
\end{aligned}
$$




\section{Kesimpulan}

a. Hasil perhitungan jarak terkecil data pasien No RM 4247 dengan data training adalah 2,24 dimana terdapat 3 data training yang sama yaitu No RM 7689, No RM 1090, dan No RM 2789. Nilai jarak terkecil menunjukkan kedekatan antara data testing (kasus baru) dengan data testing (kasus lama).

b. Nilai similarity tertinggi dari 3 data training yang memiliki jarak yang sama adalah $79 \%$, yaitu pada No RM 1090. Hasil diagnosis dari data testing adalah Diare Akut Dehidrasi Ringan. Hal ini menunjukan Algoritma K-Nearest Neighbor (K-NN) dapat digunakan untuk melakukan diagnosis pada penyakit diare yang terjadi pada balita, dengan 6 jenis klasifikasi diare yaitu diare akut tanpa dehidrasi, diare akut dehidrasi ringan/sedang, diare akut berat, diare persisten tanpa dehidrasi, diare persisten dehidrasi ringan dan dehidrasi persisten dehidrasi berat.

\section{Ucapan Terimakasih}

Ucapan terimakasih kami sampaikan kepada Kemenristekdikti atas dana hibah Penelitian Dosen Pemula (PDP) pendanaan tahun 2018. Dengan adanya dana hibah PDP, kami dapat menyelesaikan penelitian ini dengan baik.

\section{Daftar Pustaka}

[1] Gorunescu, F. (2011). Data Mining: Concepts, Models and Techniques. Data mining Concepts, Models and Technique. https://doi.org/10.1007/978-3-642-19721-5

[2] Guerrant, R. L., Van Gilder, T., Steiner, T. S., Thielman, N. M., Slutsker, L., Tauxe, R. V, ... Pickering, L. K. (2001). Practice Guidelines for the Management of Infectious Diarrhea. Clinical infectious diseases: An Official Publication of the Infectious Diseases Society of America. Cic, 32(3), 331-351. https://doi.org/10.1097/00019048200103000-00028

[3] H., A. S., Pujiastuti, A., \& Susanti, L. P. (2017). Sistem pakar untuk mendiagnosa penyakit dan hama pada tanaman salak di turi sleman, 16(1), 43-52.

[4] Indonesia, I. D. A. (2009). Pedoman Pelayanan Medis. (A. H. Pudjiadi, B. Hegar, S. Handryastuti, N. S. Idris, \& E. P. Gandaputra, Eds.). Ikatan Dokter Anak Indonesia.

[5] Kesehatan, P. D. dan I. R. (2011). Situasi Diare di Indonesia. Jakarta.

[6] Manatsthit, S. et al. (2002). Acute diarrhea in adults HISTORY AND PHYSICAL EXAMINATION. Journal of Gastroenterology and Hepatology, 17, S54-S71.

[7] RI, K. (2007). Laporan Nasional Riset Kesehatan Dasar 2007. Badan Penelitian dan Pengembangan Kesehatan Kementerian Kesehatan Republik Indonesia. Jakarta. https://doi.org/1 Desember 2013

[8] RI, K. (2013). Riset Kesehatan Dasar 2013. Jakarta: Badan Penelitian dan Pengembangan Kesehatan Departemen Kesehatan Republik Indonesia. https://doi.org/10.1007/s13398-014-0173-7.2

[9] Syaifuddin, M., \& Honggowibowo, A. S. (2014). Sistem Pakar Diagnosa Penyakit Bayi dan Balita Berbasis Android dengan Menggunakan Algoritma Depth First Search. EJournal STTA, 3(2), 27-32.

[10] Wagner, W. P. (2017). Trends in expert system development: A longitudinal content analysis of over thirty years of expert system case studies. Expert Systems with Applications, 76, 85-96. https://doi.org/10.1016/j.eswa.2017.01.028

[11] WHO. (2009). Diarrhea: Why Are Children Still Dying and What Can Be Done. The United Nations Children's Fund (UNICEF)/World Health Organization (WHO).

[12] Wilson, W. R., Lawrence, W., Drew, M., K., N., Henry, P., A., M., ... Gerberdin, M. (2001). Current Diagnosis \& Treatment in Infectious Diseases (1st ed.). New York: McGraw-Hill/Appleton \& Lange. Retrieved from http://www.medicalcity- 
iq.net/medlib/Current Diagnosis and Treatment in Infectious Diseases.pdf

[13] World Health Organization Indonesia. (2009). Pelayanan Kesehatan Anak di Rumah Sakit Pedoman bagi Rumah Sakit Rujukan Tingkat Pertama di Kabupaten/Kota.

[14] Zainuddin, M., Hidjah, K., \& Tunjung, I. W. (2016). Penerapan Case Based Reasoning (CBR) Untuk Mendiagnosis Penyakit Stroke Menggunakan Algoritma K-Nearest Neighbor. In Citesee (pp. 21-26). 